\title{
Role of ormeloxifene in the management of dysfunctional uterine bleeding: a prospective study
}

\author{
Sharda B. Ahmed ${ }^{1}$, Sushma Mogri ${ }^{1}$, Shivani Barala ${ }^{2}$ \\ ${ }^{1}$ Department of Obstetrics and Gynaecology, American International Institute of Medical Sciences, Udaipur, \\ Rajasthan, India \\ ${ }^{2}$ Department of Obstetrics and Gynaecology, RNT Medical College, Udaipur, Rajasthan, India
}

Received: 02 October 2016

Accepted: 27 October 2016

*Correspondence:

Dr. Sushma Mogri,

E-mail: docsushmamogri@gmail.com

Copyright: $\odot$ the author(s), publisher and licensee Medip Academy. This is an open-access article distributed under the terms of the Creative Commons Attribution Non-Commercial License, which permits unrestricted non-commercial use, distribution, and reproduction in any medium, provided the original work is properly cited.

\section{ABSTRACT}

Background: Menorrhagia is an important healthcare problem and most common indication for hysterectomies worldwide. This study was carried out to assess the efficacy, safety and acceptability of Ormeloxifene in the medical management of Dysfunction uterine bleeding (DUB).

Methods: For the study 50 women aged 27-48 years who attended the outpatient gynecology department in a tertiary care hospital with complaint of heavy menstrual flow were recruited. Ormeloxifene $(60 \mathrm{mg})$ was given orally twice a week for first 12 weeks and then once a week for up to next 12 weeks. The primary outcome measures were reduction in menstrual blood loss which was measured by fall in PBAC (Pictorial blood assessment chart) score, rise in hemoglobin level and reduction in endometrial thickness.

Results: The reduction in mean PBAC score at the end of 12th week was found to be statistically significant $(\mathrm{P}<0.001)$. There was also significant decrease in the mean endometrial thickness $(\mathrm{P}<0.001)$ after treatment with Ormeloxifene when compared to mean baseline value. The difference in mean hemoglobin level is $1.96 \mathrm{gm} / \mathrm{dl}$ between baseline and post treatment level was found to be statistically significant $(\mathrm{P}<0.001)$. No major adverse effects were experienced by patients in this study.

Conclusions: Ormeloxifene is very effective and safe alternative in the management of dysfunction uterine bleeding. It has a good patient acceptability and compliance due to its minimal side effects, low cost and simple dosage.

Keywords: Dysfunctional Uterine Bleeding, Menorrhagia, Ormeloxifene

\section{INTRODUCTION}

Dysfunction Uterine Bleeding (DUB) is a state of abnormal uterine bleeding without any clinically detectable organic, systemic and iatrogenic cause. ${ }^{1}$ It is the most common menstrual disorder among women in all age groups and accounts for $20 \%$ of gynaec OPD. ${ }^{2}$

Menorrhagia is defined as cyclical bleeding at normal intervals which is excessive in amount (Total blood loss greater than $80 \mathrm{ml}$ ) or duration (lasting longer than 7 days). ${ }^{3}$ It affects $10-33 \%$ of women at some stage of their lives. DUB is one of the most common causes of iron deficiency anemia in females after nutritional anemia.

A wide range of treatment modalities are available which include medical therapy and surgical interventions. Medical management of menorrhagia is a challenging task and includes hormonal or non-hormonal agents. Hormonal agents include estrogens, progesterone and combination of the two, androgens, danazol, GnRH agonists and the latest SERMS (Selective Estrogen 
Receptor Modulators). Non hormonal drugs like NSAIDS, ethamsylate and anti-fibrinolytics have also been found to be highly effective. Medical management has always been the first therapeutic option to be tried and if it fails to show results, one can resort to surgical interventions. Hysterectomy should be the last resort in the management of DUB. Because of the morbidity associated with the surgical procedures the RCOG recommends beginning with medical management before resorting to surgical intervention. The latest of the pharmacological agents that have become available for the treatment of DUB are selective estrogen receptor modulators or SERM.

Ormeloxifene is an III generation SERM. It is a non hormonal, non steroidal drug primarily used as a contraceptive, but it may also be effective for dysfunctional uterine bleeding and advanced breast cancer. It is anti-estrogenic on endometrium and breast while estrogenic on bones, vagina and cardiovascular systems. ${ }^{4}$

\section{METHODS}

This prospective study was conducted in the Department of Obstetrics and Gynecology, American International Institute of Medical Sciences, Udaipur during the period of Jan 2016 to Aug 2016.

\section{Selection criteria}

For the study 50 Women aged $27-48$ years who attended the outpatient gynecology department with complaint of abnormal uterine bleeding were recruited. Ethical approval was obtained from the institutional ethical committee.

\section{Exclusion Criteria}

- Postmenopausal bleeding.

- Pelvic pathologies like uterine fibroids / adenomyosis / endometrial polyp.

- Malignancies of uterus / cervix / ovary / vagina and endometrial hyperplasia with atypia.

- Bleeding dyscrasia.

- Medical disorders like liver dysfunction, heart disease, migraine stroke, renal disease and thyroid disorders.

- $\quad$ Pregnancy, Abortion or women desirous of fertility.

- Hypersensitivity to the drug.

The Patients meeting the inclusion criteria were explained in detail about the nature of the study, its purpose, regimen procedure and follow up. Informed consent was taken from all the patients. A detailed history and clinical examination was done. As DUB is a diagnosis of exclusion, investigations were done to rule out any other possible causes for abnormal uterine bleeding. These included complete blood cell count including Hemoglobin (Hb) level, Thyroid stimulating hormone, coagulation profile, Pap smear, pelvic ultrasound to measure endometrial thickness and rule out any pelvic pathology and endometrial sampling.

The cases were advised to maintain a menstrual diary to record the total number of days of bleeding, number of sanitary pads used, degree of soaking of each pad, number and size of clots passed and if dysmenorrhoea experienced. The pictorial blood loss assessment chart (PBAC) scoring was done accordingly to assess menstrual blood loss. ${ }^{5}$ PBAC is a simple procedure for objective assessment of menstrual blood loss, a method that correlates well with the alkaline haematin test. ${ }^{6} \mathrm{~A}$ PBAC score $\geq 100$ indicate a menstrual blood loss $\geq 80$ $\mathrm{ml}$ and is considered diagnostic for menorrhagia (Table $1) .^{5}$

Table 1: PBACa scoring system.

\begin{tabular}{|c|c|c|}
\hline$? ? ?$ & ???? & ??? \\
\hline \multirow{3}{*}{ Pads } & Lightly soiled & 1 \\
\hline & Moderately soiled & 5 \\
\hline & Saturated & 20 \\
\hline \multirow{2}{*}{ Clots } & $\begin{array}{l}\text { Small (Smaller than a } \\
\text { rupee coin) }\end{array}$ & 1 \\
\hline & $\begin{array}{l}\text { Large (Larger than a } \\
\text { rupee coin) }\end{array}$ & 5 \\
\hline
\end{tabular}

All cases were given Ormeloxifene $60 \mathrm{mg}$ twice a week for 12 weeks and then once a week for next 12 weeks. Treatment schedule was continued irrespective of menstrual period. Follow up was done at 1 and 3 months or earlier if needed. During each visit a detailed menstrual history was taken. The primary outcome measures were reduction in amount of menstrual blood loss which was assessed by fall in PBAC score, rise in hemoglobin level and reduction in endometrial thickness done in proliferative phase by a transvaginal ultrasound.

The secondary outcome measures were the acceptability and side effects of Ormeloxifene. Subjective assessment of the improvement of symptoms was also done. PBAC score, hemoglobin concentration and endometrial thickness were measured before the start of therapy, at 1 and 3 months.

\section{RESULTS}

The data obtained was analyzed using the student's paired t-test, wilcoxon sign rank test and the difference between the two proportions of the nominal data was analyzed by Z-test.

Out of 50 patients enrolled, 41 completed the study and 9 lost the follow up. Age of the treated patients ranged between 27-48 years and maximum number of patients 
were in the age group between $35-45$ years (52\%). Table 2 represents that there was significant decrease of median PBAC score from baseline to $12^{\text {th }}$ week of treatment follow up and the reduction was found to be statistically significant $(\mathrm{P}<0.001)$.

21 out of 41 patients $(51 \%)$ recorded an average PBAC score of less than 100 at the end of study. There was a significant reduction of endometrial thickness $(\mathrm{P}<0.001)$ majority of patients had anemia when enlisted into the study as defined by WHO (hemoglobin $<12 \mathrm{gm} / \mathrm{dl}$ ). There was a significant increase in post treatment hemoglobin level when compared to baseline hemoglobin level. The mean increase of $1.96 \mathrm{gm} / \mathrm{dl}$ of hemoglobin level was statistically significant $(\mathrm{P}<0.001) .68 \%$ of patients had significant relief from passage of clots $(\mathrm{P}<0.001)($ Table 2).

Table 2: Outcome measures of study (after 3 months).

\begin{tabular}{|c|c|c|c|c|c|c|}
\hline Sr. No. & Outcome parameter & $\mathbf{N}^{\mathrm{a}}$ & Pre treatment & Post treatment & Test & P value \\
\hline 1 & PBAC score (Median) & \multirow{5}{*}{41} & $\begin{array}{l}320 \\
(202-393)\end{array}$ & $\begin{array}{l}96 \\
(82-110)\end{array}$ & $\begin{array}{l}\text { Wilcoxon sign rank test } \\
Z=5.576\end{array}$ & $\mathrm{P}<0.001^{*}$ \\
\hline 2 & $\begin{array}{l}\text { Endometrial thickness } \\
(\mathrm{mm})(\text { Mean } \pm \mathrm{SD})\end{array}$ & & $11.13 \pm 2.95$ & $7.05 \pm 2.13$ & $\mathrm{t}=12.94$ & $\mathrm{P}<0.001^{*}$ \\
\hline 3 & $\begin{array}{l}\text { Hemoglobin level } \\
(\mathrm{gm} \%)(\text { Mean } \pm \mathrm{SD})\end{array}$ & & $8.85 \pm 1.37$ & $10.81 \pm 0.89$ & $\mathrm{t}=25.878$ & $\mathrm{P}<0.001^{*}$ \\
\hline 4 & Presence of clots & & $32(78.05 \%)$ & $10(24.39 \%)$ & $\mathrm{z}=4.640$ & $\mathrm{P}<0.001^{*}$ \\
\hline 5 & Dysmenorrhea & & $25(60.98 \%)$ & $6(14.63 \%)$ & $\mathrm{z}=4.099$ & $\mathrm{P}<0.001^{*}$ \\
\hline
\end{tabular}

$\mathrm{a}=\mathrm{N}=$ total number of patients followed up

${ }^{*}$ Significant $\mathrm{P}$ value

Subjects with PBAC scores $>100$ and those who opted for surgical treatment were taken as failure of treatment. In our study $7(17 \%)$ patients failed to respond to Ormeloxifene. Out of that $3(7 \%)$ women who do not respond to Ormeloxifene were switched to other medical management. Only $4(10 \%)$ patients underwent surgery which was significantly less.

During the study period there were no major side effects, the observed effects were amenorrhea in $4(9.76 \%)$, giddiness in $3(7.32 \%)$ and abdominal pain in $2(4.89 \%)$ which did not require termination of treatment (Table 3 ).

Table 3: Distribution of side effects.

\begin{tabular}{|ll|}
\hline Side effects & Number of patients \\
\hline Amenorrhoea & $4(9.7 \%)$ \\
\hline Giddiness & $3(7.32 \%)$ \\
\hline Abdominal pain & $2(4.88 \%)$ \\
\hline
\end{tabular}

\section{DISCUSSION}

Dysfunctional uterine bleeding is the diagnosis in a majority of the cases of menorrhagia. The symptom of menorrhagia accounts for a significant proportion of the referrals to gynecologists. DUB is considered a diagnosis of exclusion. A medical management is the first line of therapy for DUB. Among the Pharmacological agents, some are effective only for anovulatory DUB; some are useful only for ovulatory DUB and still others may be effective for both.

In our study we have analyzed the efficacy of Ormeloxifene in patients with DUB and our results suggested that there was a significant reduction of menstrual blood loss. These results are similar to other studies. ${ }^{7,8}$ The results of the present study showed that there was a significant rise of hemoglobin level which was also similar to other studies. ${ }^{7-9}$ When endometrial thickness was compared between baseline and post treatment period, there was a significant reduction with this drug. These results are similar to other studies. ${ }^{7-10}$

Ormeloxifene is very effective in improving all the parameters of blood loss in DUB. ${ }^{11}$ It has got an excellent safety profile and has been found to have very few side effects.

Considering the cost and complications of surgical treatments, medical therapy should always be tried first in cases of DUB. Ormeloxifene has the potential to be an effective treatment of DUB and should always be considered amongst the treatment options.

Limitations of present study include the absence of double blind placebo controlled method to eliminate information bias. Randomized controlled trials with larger subjects are needed to throw light regarding the efficacy and safety of the agent.

\section{CONCLUSION}

Dysfunctional uterine bleeding is a common problem that is encountered in the gynaecology department. The main mode of management is pharmacological therapy. Ormeloxifene was found effective and appears to be a promising option for the medical management of DUB. It leads to a significant reduction in menstrual blood loss, a 
significant rise in hemoglobin concentration and a significant decrease in endometrial thickness.

Along with being effective, the drug has a good patient acceptability and compliance due to its minimal side effects, low cost (compared to all alternative medical and surgical treatments) and simple dosage schedule. It can be used in any age group and is oncologically protective to the breast and endometrium. Though the study size is small it highlights the role of Ormeloxifene in reduction of menorrhagia and avoiding surgery in peri-menopausal women with proper follow up.

\section{ACKNOWLEDGEMENT}

We, acknowledge our thanks to our patients and their friends who bestowed their trust on us and enabled us to show light to others in this regard.

Funding: No funding sources Conflict of interest: None declared

Ethical approval: The study was approved by the Institutional Ethics Committee

\section{REFERENCES}

1. Bravender T, Emans SJ. Menstrual disorders. Dysfunctional uterine bleeding. Pediatr. Clin North Am. 1999;46(3):545-53.

2. Awwad JT, Toth TL, Schiff I. Abnormal uterine bleeding in the perimenopause. Int $\mathrm{J}$ Fertil. $1993 ; 38 ; 261$.

3. Bhatia N. Abnormal and Excessive uterine bleeding. In Neeraj Bhatia editor. Jeffcoate's Principles of
Gynecology. 5th Edition. London: Arnold Publishers; 2001:560.

4. Sharma S, Kaur D, Mahajan A, Tandon V. Selective oestrogen receptor modulators. Asian Journal of obstetrics and gynaecology practice. 2006; 1013:306.

5. Higham JM, O'Brien PMS, Shaw RW. Assessment of menstrual blood loss using a pictorial chart. Br J Obstet Gynaecol. 1990;97:734-39.

6. Biswas SC, Saha SK, Bag TS. Ormeloxifene a selective estrogen receptor modulator, for treatment of dysfunctional uterine menorrhagia. J Obstet Gynaecol Ind. 2004;54(1):56-9.

7. Kriplani A, kulshresha V, Agarwal N. The efficacy and safety of Ormeloxifene in the management of Menorrhagia: a pilot study. J. Obstet. Gynecol. 2009;35(4):746-52.

8. Dhananjay BS. Nanda SK. Role of sevista in management of uterine bleeding. Journal of clinical diagnostic and Research. 2013;7(1):132-34.

9. Sudha Prasad. Centchroman - A novel drug for DUB. J obstet Gynecol Ind. 2000;50(2).

10. Hallberg L, Nillsson L. Determination of menstrual blood loss. Scand J clin Lab Invest. 1964;16:244-48.

11. D. BS and Nanda SK. The role of Sevista in the management of Dysfunctional Uterine Bleeding, J Clin Diagn Res. 2013;7(1):132-4.

Cite this article as: Ahmed SB, Mogri S, Barala S. Role of ormeloxifene in the management of dysfunctional uterine bleeding: a prospective study. Int J Reprod Contracept Obstet Gynecol 2016;5:4373-6. 